Saska PETROVA

Stefan BOUZAROVSKI

Martin ČIHA ̌̌

\title{
Conservationist or fashionista? Urban dwellers' expectations from national parks in the Republic of Macedonia
}

This paper focuses on the long-standing knowledge divide regarding urban dwellers' perceptions of, and attitudes towards, environmental management and protection in national parks in general and South Eastern Europe more specifically. The factors that lead contemporary tourists to visit such areas often remain unclear and inadequately connected to contemporary social science research. Therefore, we explore the profile and needs of urban visitors to the Pelister National Park in the Republic of Macedonia, with the aim of investigating the extent to which their motivation is driven by an intrinsic engagement with the natural features of the area itself, as opposed to a more superficial interest in its symbolic brand. The results of this paper, which lean towards the latter, emphasise the need for the development of an effective visitor management strategy as an integral part of the overall governance of national parks.

Keywords: nature protection, tourism, national parks, South-Eastern Europe, Macedonia 


\section{Introduction}

The importance of protected areas as 'sanctuaries', for urban dwellers has always been a topical issue within academic literature. Many authors - including psychologists and natural scientists - believe that national parks, with their natural beauty and 'peacefulness' have made a significant contribution to urban dwellers' social and psycho-physical needs (see Hartig, 1993; Obua and Harding, 1996; Chiesura, 2004; Sanesi et al., 2006; Matsuoka and Kaplan, 2008; Petrova et al., forthcoming; Suckall et al., 2009). In England, for example, the manner in which the countryside has shaped the national identity over time has been extensively emphasised and discussed in relation to the broader cultural, social and political developments (i.e. Taylor, 1995; Agyeman and Spooner, 1997; Edensor, 2000; Suckall et al. 2006).

However, there is still an empirical divide regarding urban dwellers' perceptions of, and attitudes towards, national park management and protection: their motivations for visiting such areas remain unclear and inadequately connected to contemporary social science research regarding the relationship between nature conservation and tourism. There is also a need for additional inquiry into the urban dwellers' influence upon the parks themselves, as well as their interaction with local communities. This is particularly true in post-communist states such as those in South-Eastern Europe, where many national parks are still lacking any degree of monitoring capacity - and consequently the necessary political strategies - for visitor management, despite the extensive structural changes experienced by such societies over the past 20 years.

The deficiency of scientific research regarding the relationship between national park visitors and the governance of protected area is even more evident in the Republic of Macedonia, which has a specific situation in this regard, due to the presence of large urban populations in the immediate proximity of protected areas (EAR, 2003). The country is also characterised by a lack of adequate environmental management frameworks, especially in response to increasing tourist pressure in protected areas. Therefore, this paper looks at the manner in which the motivations, perceptions and movements of national park visitors actually relate to the protected areas themselves. Based on the primary research undertaken in the Pelister National Park - on of the oldest such protected area in South-Eastern Europe, lying very close to an urban centre, with approximately 100,000 inhabitants - it identifies the profile and needs of urban visitors to the park, while exploring their needs and aspirations. These are compared with the results from similar case studies and placed in the context of the broader relationship between nature conservation and tourism activity.

\section{Aims and methods}

The broader purpose of this paper is to explore the motivations that drive contemporary tourists to visit protected areas in South-Eastern Europe. We investigate the demographic profile and socio-cultural expectations of urban visitors to the Pelister National Park in the Republic of Macedonia. This paper aims to assess the extent to which their decision to come to the park is driven by the intention to develop an intrinsic engagement with the natural features of the area, as opposed to a more superficial interest in its symbolic importance.

Our research is based on the quantitative and qualitative evidence regarding the features and expectations of urban tourists to the Pelister National Park, gathered between the $18^{\text {th }}$ and the $26^{\text {th }}$ of August 2006. The period was deliberately chosen so as to include two weekends during the height of the tourist season. Using a pre-set questionnaire, we approached visitors at the main entry point to the park (Figure 1 ) at 10 to 15 minute intervals, between $7 \mathrm{AM}$ and $3 \mathrm{PM}$ each day. We received 230 responses out of a total of 265 individuals who were approached, giving us a response rate of $87 \%$.

The interview questions focused on:

- The socio-demographic characteristics of the respondents;

- The frequency of their visits, length of stay in the park and the method of movement (i.e. by car, by foot); and

- The visitors' needs, attitudes towards and perceptions regarding the protection and management of the Pelister National Park.

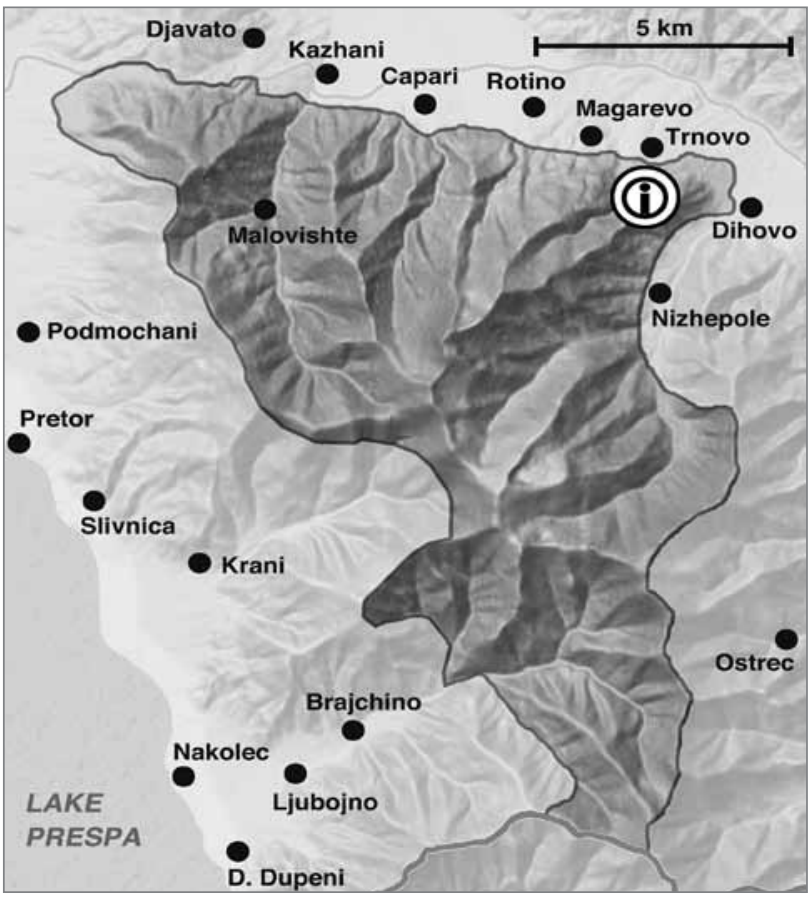

Figure 1: Salient features of the Pelister National Park. The survey point is marked with an 'i' (illustration: Stefan Bouzarovski). 
The questionnaire structure and sampling approach utilised by the survey was based upon the methodology that has been developed and implemented in the Czech Republic for approximately 10 years (see Cihar and Stankova, 2006). By using this approach we hoped to provide for a greater degree of comparability between our study and similar work undertaken in the Czech Republic and elsewhere in Central Europe (see Petrova et al., forthcoming).

The questionnaire survey was supplemented by 10 in-depth interviews with national park officials and local inhabitants, in order to highlight the broader structural relationship between nature protection and local communities, as well as the institutional conditions that serve as a policy background toward tourism in the area. In this paper, the results of both sets of data have been compared to the outcomes of an earlier research project with similar aims, undertaken during the winter of 2003, under the auspices of the European Agency for Reconstruction (EAR).

\section{Urban visitors to national parks: Making the connection}

Political ecologists and economic historians have located the emergence of protected areas within a romantic strive to 'modernise' cities during the industrial revolutions which engulfed Western Europe in the nineteenth century. Suckall et al. (2009) argue that the romantic movement of the nineteenth century attempted to offer an alternative to the smoke stacks of the industrialising economies. In abandoning the principles of science and reason, the romantics stressed the power of the imagination, feelings and emotions. They focused their attention on the aesthetics of the natural world, transforming places that had once been seen as 'valueless' into 'picturesque and sublime' natural refuges (ibid.). Solitude and escape from the city thus became "bound up with notions of individuality and self development, with a retreat from the city and the urban self and towards a freeing of the body, a rediscovery of childish sensation, and aesthetic and moral regeneration" (Edensor, 2000: 84).

However, this trend had an important class dimension, as the UK's national parks, for example were generally placed in regions that affluent, university-educated white people deemed important (Suckall et al., 2009). This means that their aesthetics was perceived and designed by individuals who had been educated in the Romantic idea of 'wilderness and solitude' (ibid.). The upper class romantics were keen to keep the landscape exclusive for those who had the "financial and cognitive" resources to appreciate "scenery, landscape, image, [and] fresh air" (Williams, 1972: 6). It can be argued, that national parks are often managed to preserve tranquillity and 'naturalness' even if this results in a contrived landscape. Suckall et al. (2009) point out that such an approach leaves little room for dynamism and evolution, since any transformations may be seen as less aesthetically desirable by national park visitors. Their findings signal an important, albeit subtle shift in the social role of protected areas: they have gradually moved from acting as the providers of a romantic 'escape' from the contamination of the city, to active players in the formation of the identities and lifestyles of their visitors.

The fact that urban dwellers' preferences and needs regarding natural sites have varied through time and space has also been picked up by authors such as Bauen et al. (2008) and Matsuoka and Kaplan (2008); in order to determine the changing character of contemporary urban perceptions of nature, the latter have undertaken a comprehensive analysis of 58 volumes of the journal Landscape and Urban Planning, discovering that much of the surveyed work addresses nature as a place that can help improve the quality of life and provide a brief sanctuary from 'urban problems'.

However, more recently there has been increasing academic interest in the role of visits to protected nature areas as a signifying symbol of status, fashion and also a healthy lifestyle. The main question in this context pertains to the tension between the urban dwellers' desire to explore and protect nature, on the one hand as opposed to their interest toward entertainment and relaxation, on the other. Considering that the latter can be provided even at the gateways of national parks, Beunen et al. (2008) have stressed that most urban dwellers rarely venture into the core of protected areas, choosing to use the gateways for recreational activities. Similarly, Sterl et al's (2008) assessment of the awareness of the disturbance of wildlife due to different anthropogenic uses - including recreational activities - amongst on-site visitors in the Donau-Auen National Park, Austria, showed that only $12 \%$ of the respondents believed that they could have potentially disturbed wildlife on the day of the interview.

The mass endorsement of an active and healthy lifestyle, which helps reaffirm the connection between individuals and nature (Eagles and McCool, 2002) has combined with the expansion of low-cost airlines to make nature conservation areas and activities around the world more easily visible and accessible, thus further accelerating the development of nature-based tourism. The effects of such developments are particularly pronounced in national parks, as, according to Obua and Harding (1996), people are generally more attracted to a particular area if they know that it has been designated for protection, since this affects the perception of its attributes and natural beauty. But even though the ideology behind nature-based tourism is ba- 
sed on nature protection principles and guidelines, its environmental consequences can potentially be more damaging than mass tourism, primarily because they are mainly concentrated in sensitive and vulnerable areas (Gössling, 1999). The increasing interest in nature-based tourism within protected areas, especially those located in developing countries, is also magnifying and diversifying its implications for the development of local communities (Goodwin, 1996; Lindberg and Johnson, 1997). This means that the impacts of tourism activities in this domain extend beyond the natural environment (Goodwin, 1996), since they also affect the socio-economic processes and municipal governance.

It should be pointed out that there isn't a single, linear relationship between visitors and local communities. According to Eagles and $\mathrm{McCool}$ (2002), interactions between visitors and local communities can include cultural (exchange of folkloric and traditional habits, customs and beliefs), economic (investment, a boost to the local economy, changing labour markets), demographic (changes in population structures, migration processes), environmental (pollution, destruction of natural sites, natural habitat disturbances) and political (changing laws, designation of more protected areas as a result of increased awareness and appreciation for parks) dimensions. That is one of the main reasons why Mehta and Kellert (1997) argue in favour of an integrated and simultaneous planning of local development, including tourism and nature protection. Indeed, as Obua and Harding (1996: 505) point out, "understanding visitor characteristics is a principal aspect of sustainable tourism" and "planning of new developments, management of visitors, monitoring trends and predicting recreational demands, all require adequate information on visitors".

In this context, it is worth mentioning Bourdieu's (1986) maxim that a person's 'lifestyle' is a trade-off between preferences relating to leisure, culture, consumption, and cultural tastes. Therefore many authors stress the need for establishing the profile of national park visitors within the framework of their affiliation to a particular social group, and in terms of their individual preferences for different cultural and leisure activities (Urry, 1990; Featherstone; 1991; Suckall et al., 2009). According to Breakell (2002) most of the national park visitors in Britain and Western Europe are from a middle class background; a finding that is also supported by, inter alia, Agyeman (1995), Agyeman and Spooner (1997), and Breakell (2002). Similarly, Obua and Harding's (1996) work in Uganda has indicated that most visitors (52\%) to the Kibale National Park are university graduates. Petrosillo et al. (2007) discovered that marine protected areas in Italy had a higher rate of male visitors, whose overall sample was dominated by the $31-45$ age bracket and individuals with a secondary education.
The national park visitor profile in Central and Eastern Europe appears to be similar to the one established for Western Europe, albeit with some exceptions. In the Czech Republic, Cihar and Stankova (2006) found that male respondents do not outnumber female respondents, as in many cases there are more female respondents or both genders are represented equally. The age structure of national park visitors varies in space and time (Beunen et al., 2008), such as during winter periods and in protected mountainous areas, where most of the visitors are in the 25-39 age bracket, while the 40-59 age bracket is more typical for summer periods. Also, Cihar and Stankova (2006) have noted that the number of visitors with a university degree has been on the rise since the 1990s.

The formulation of a visitor management strategy, within the comprehensive management plans of protected areas must be predicated on an adequate understanding of visitors' preferences and perceptions. Petrosillo et al. (2007) argue that the socio-economic status, cultural ties, and past experiences are key factors in influencing the perception of environmental quality. The preferences of urban dwellers towards activities in national parks can differ in numerous ways, based on their personal characteristics, education levels and their place of residence (ibid.). For example, Matsuoka and Kaplan (2008) have underlined that younger people are attracted toward more active pursuits (i.e. sports activities), while adults and the elderly would rather enjoy natures opportunities, which afford observation and relaxation (Oguz, 2000; Sherman et al., 2005; Oku and Fukamachi, 2006). Moreover, it is thought that urban dwellers show a greater interest in enigmatic and exotic environments (Herzog et al., 1989; Ulrich et al., 1991; Hartig, 1993). In light of the diversity of visitors' needs and expectations, many authors believe that measures to influence tourist behaviour should be principally be aimed at preserving the balance between nature and recreation (see Reynolds and Elson, 1996; Cope et al., 1999; Beunen et al., 2008).

\section{Spatial context of the study}

The Republic of Macedonia has made a number of policy steps aimed at harmonising its nature protection regulation in line with that of the EU, as a result of its desire to join the 27-nation states. However, the regulatory frameworks for nature protection - especially with regard to the management of protected areas - are still insufficiently developed. This is accompanied by an almost complete lack of scientific research looking into the relationship between tourism and nature protection, a situation that has transpired, despite the fact that the country's three national parks - Galichica, Mavrovo and Pelister - are also amongst its top tourist destinations. 
Pelister is the first national park in the Republic of Macedonia and one of the oldest such protected areas in the Balkans, having been founded in 1948. It is an IUCN II category protected area within Macedoniass nature protection framework. The park lies in the south-western part of the country, adjacent to the border with Greece and less than 15 kilometres away from Macedonia's second largest city, Bitola. It presently covers a total area of 14,300 hectares, thanks to the expansion of its boundaries in 2007 (Petrova et al., forthcoming). The park's territory coincides with the central portions of the Baba mountain massif occupying altitudes ranging from between 891 to 2,601 metres above sea level (see Figure 1). As such, it includes extensive forested areas of Macedonian pine (Pinus peuce), which extend across a relatively large part of the park's northern slopes and are among the Balkans' best-developed and most extensive ecosystems, formed by this very rare and endemic pine (Nastov and Micevski, 1994; Nastov, 2000).

Although there is only one rural settlement - the village of Malovishta - within the Pelister's boundaries, a number of villages that are well known for their cultural and architectural heritage line the boundaries of the park, including, inter alia, Brajchino, Kazhani, Rotino, Capari, Magarevo, Trnovo, Dihovo, and Nizhepole (EAR, 2003). The settlements contain a unique complex of stone masonry houses, dating from the nineteenth century (see Figure 2).

\section{Socio-demographic features of urban visitors to the Pelister National Park}

The questionnaire survey that we undertook in the Pelister revealed, that male visitors to the park outnumbered female ones by almost a 2:1 ratio, as their respective proportions in the survey sample reached $62 \%$ and $38 \%$. At the same time, most respondents belonged to the 40-59 age group (41\%), with a significant number between 25 and 39 years of age (37\%). Those who were older than 60 or younger than 17 , formed equal proportions of the sample ( $8 \%$ each), with an even smaller share $(6 \%)$ being represented by the 18-24 age group. The largest visitor numbers were recorded between 1 and 3 PM (Figure 3).

Regarding the employment of the respondents, it transpired that the majority of them $(56 \%)$ were working in the tertiary or quaternary sector, with a further $15 \%$ belonging to the primary and secondary sector. It should be noted that $12 \%$ of the respondents were unemployed, $11 \%$ were students and $6 \%$ were retired. Nearly half of the respondents (45\%) had a tertiary education, while a further third (32\%) had managed to

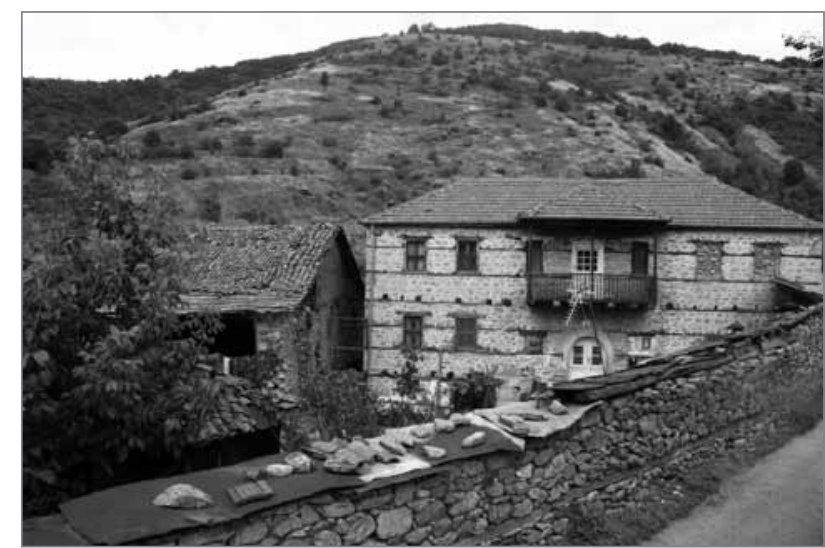

Figure 2: Traditional architecture in the village of Brajchino (photo: Stefan Bouzarovski).

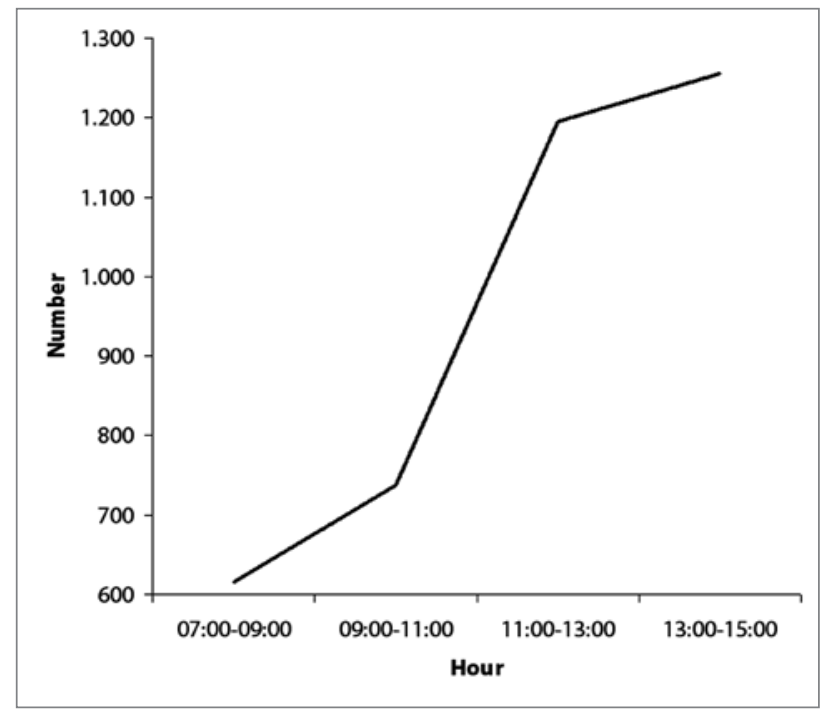

Figure 3: Diurnal trends in visitor frequencies at the survey point $(\mathrm{N}=230)$.

complete secondary schooling. An overwhelming share (74\%) of the visitors, were from the nearby city of Bitola.

When compared to the results of the EAR study (EAR, 2003), it emerged that the only similarity in both cases was that male respondents outnumbered female respondents. Most visitors in the EAR sample were from the 17-24 age group, which also means that visitors with a lower educational level prevailed ( $52 \%$ of all respondents had a secondary school diploma). It should be noted that once again, this study was undertaken during the winter period. As pointed out by 'Vesna', a 57 year old private entrepreneur from Bitola:

I don't come here in winter /.../ I don't ski and the hotels are usually full of noisy teenagers /.../ I and my husband prefer Pelister in summer, the air is so clean and cool here. I cannot take time off from my business, maybe just on Sundays. Then we come here and have a coffee or lunch in the shade. 
Similarly, 'Vaska', a 45 year old government employee, also from Bitola, pointed out:

I would say that you get a particular demographic here in Pelister /.../ Mainly middle-aged people or pensioners. We are like a little community of regulars and it's a big thing to be seen here, in the Molika hotel, drinking coffee or taking walks in the area. It is good for your health!

On the whole, the profile of urban visitors to Pelister corresponds with the common pattern of city dwellers visiting protected areas in Europe, during both the summer and winter seasons, with some exceptions regarding the gender structures observed in Central Europe.

\section{Visitor needs and expectations}

When asked about the frequency and length of their visits to and stays in the national park, $96 \%$ of the tourists surveyed, answered that they had already visited the area in the past. Although most of them pointed out that they usually visit the park during the summer months (57\%), a third (34\%) stated that they tended to come to the park during the winter months, with the remainder being split evenly between the autumn and the spring. Around $89 \%$ of the respondents answered that they intended to stay only for one day in the park, while $7 \%$ of them were staying for two days and only $4 \%$ were planning to spend a whole weekend in Pelister. It should be emphasised that $89 \%$ of the respondents were using automobiles as their mode of transportation to and from the park, while $8 \%$ came by motorcycle and a meagre $3 \%$ by bicycle.

The main reason for almost all the surveyed tourists visiting the park, were its natural features (98\%), although they did not demonstrate a special need for further exploration or educational activities. The majority of them (76\%) pointed out that they would rather enjoy their meal or refreshment in the nearby restaurant in a natural surrounding. As indicated by 'Marko', a 32 year old engineer from Bitola:

Yes, sure, the moraines or pine forests sound great, but frankly, I don't have time to go up there /.../ Golema Livada [authors' note - located at the entrance of the park] is so nice, you can drive here by car and bring your children to breathe some fresh air. Plus many of our friends come here too.

It is interesting that the percentage of respondents who preferred 'peaceful relaxation' (90\%) was larger than the number (70\%) of those who came to the park for different sports activities. Out of all the interviewed visitors, only $3 \%$ visited the park for its cultural-educational activities. The sport activities identified by the respondents included, hiking (57\%), picking forest fruits (26\%) and observing nature (17\%). Almost half (49\%) of the surveyed tourists thought that they had observed an improvement in the state of the environment of the park during the last five years, although $36 \%$ felt that things had remained unchanged, while $4 \%$ thought that it had actually become worse and $11 \%$ didn't reply. Two thirds of the respondents were satisfied with the quality of the information system in the park, while a quarter were not satisfied. Most of the respondents (87\%) felt that the most endangered parts of the park should be open to visitors without any restrictions.

The respondents underlined the proximity to the city (only around 15 kilometres) and offered amenities, especially with respect to the well-known hotel-restaurant, as an important factor for the frequency of their visits. This also came through in the interview with 'Bojan', a 67 year old pensioner from Skopje:

The nice thing about Pelister, is that it is really close to the city of Bitola. It is practically a part of the city, an extension of it. But a nice extension, without pollution, without the crowds! You don't have to walk very far to enjoy it. And you don't even have to have your own car /.../ You can take a taxi and then walk up, it is not expensive.

\section{Conclusion}

To summarise, the reviewed quantitative and qualitative evidence has indicated that the main motivation for the urban dwellers' visits to Pelister, lies in the natural amenities offered by the national park, as well as the cultural brand associated with its image as a protected area. It should be pointed out that that although the respondents had a general knowledge about Pelister as a designated national park, they lacked a significant awareness about their own impact upon the environment, as well as an active readiness to take part in its protection. In part, this is also supported by the fact that the overwhelming majority of the visitors came by automobiles and only stayed in the area for one day.

The findings of this paper also support the suggestion that that there is a strong relationship between the place where people park their automobiles and the facilities offered at that location. The main road in the park actually connects Bitola with the largest and the most popular hotel-restaurant ('Molika'), which is also one of the main focal points within this area and can be considered a gateway to the park. The implications of this finding for the management of visitor flows and national park protection is in line with Beunen et al. (2008), who have found that the creation of a gateway in a nature conservation 
area will help concentrate the traffic flows in the vicinity of the gateway.

Taking into consideration Eagles and McCool's (2002) argument, where visitors from different age and social groupings have different needs, one would have expected that most of the urban dwellers involved in our research would opt, with respect to both a physical and relaxation perspective to actually be less demanding. The results of this survey confirmed this pattern, as $90 \%$ of the respondents stated that they preferred 'peaceful relaxation' in the park. It is important to note that approximately two thirds of the surveyed visitors did not demonstrate a further interest in exploring or observing the natural features of the park. Clearly, the promotion of protected area tourism as a 'healthy lifestyle' option in Macedonia, is making national parks fashionable for an increasing number of urban dwellers, without bringing about an associated rise in nature protection awareness. This emphasises the need for the development of an effective visitor management strategy as an integral part of the overall governance of national parks.

Saska Petrova, Environmental Scientist, Ph.D. Candidate

Charles University in Prague, Faculty of Science, Institute for Environmental Studies, Prague, Czech Republic

E-mail:petrova3@natur.cuni.cz

Dr. Stefan Bouzarovski, Geographer, Lecturer in Human Geography University of Birmingham, School of Geography, Earth, and Environmental Sciences, Birmingham, United Kindgdom

Visiting Professor, Charles University in Prague, Faculty of Science, Department of Social Geography and Regional Development, Prague, Czech Republic

E-mail: buzars@adf.bham.ac.uk

Dr. Martin Čihař, Environmental Scientist, Associate Professor Institute for Environmental Studies, Faculty of Science, Charles University in Prague, Prague, Czech Republic

E-mail:mcihar@natur.cuni.cz

\section{Notes}

Stefan Bouzarovski's work on this paper was supported by the Ministry of Education, Youth and Sports of the Czech Republic, project no. MSM0021620831: 'Geographic Systems and Risk Processes in the Context of Global Change and European Integration'. Stefan Bouzarovski is also an External Professor at the Institute of Geography, University of Gdansk, Piłsudskiego 46, Gdynia, Poland.

\section{Acknowledgements}

The authors wish to thank the Pelister National Park Authority and the Biosfera NGO for their kind and generous support throughout the background research for this study.

\section{References}

Agyeman, J. (1995) Environment, heritage and multiculturalism. Journal of the Association of Heritage Interpretation, 1(1), pp. 5-6.
Agyeman, J., and Spooner, R. (1997) Ethnicity and the rural environment. In: Cloke, P., and Little, J. (eds.) Contested countryside cultures: Otherness, marginalisation and rurality, pp. 197-217. London, Routledge.

Beunen, R., Regnerus, H. D., and Jaarsma, C. F. (2008) Gateways as a means of visitor management in national parks and protected areas. Tourism Management, 29(1), pp. 138-145.

Bourdieu, P. (1986) Forms of capital. In: Richardson, J. (ed.) Handbook of theory and research in the sociology of education, pp. 241-258. New York, Greenwood Press.

Breakell, B. (2002) Missing persons: Who doesn't visit the people's parks? Countryside Recreation, 10(1), pp. 13-17.

Chiesura, A. (2004) The role of urban parks for the sustainable city. Landscape and Urban Planning, 68(1), pp. 129-138.

Cihar, M., and Stankova, J. (2006) Attitudes of stakeholders towards the Podyji/Thaya River Basin National Park in the Czech Republic. Journal of Environmental Management, 81(3), pp. 273-285.

Cope, A., Doxford, D., and Millar, G. (1999) Counting users of informal recreation facilities. Managing Leisure, 4(4), pp. 229-244.

Eagles, P. F. J., and McCool, S. F. (2002) Tourism in national parks and protected areas: Planning and management. Wallingford, $C A B$ Publishing.

Edensor, T. (2000) Walking in the British countryside: Reflexivity, embodied practices and ways to escape. Body and Society, 6(3), pp. 81-106.

EAR - European Agency for Reconstruction (2003) Pelister tourism development study: Development concept report. Thessaloniki.

Featherstone, M. (1991) Consumer culture and postmodernism. London, Sage.

Goodwin, H. (1996) In pursuit of ecotourism. Biodiversity and Conservation, 5(3), pp. 277-291.

Gössling, S. (1999) Ecotourism: A means to safeguard biodiversity and ecosystem functions? Ecological Economics, 29(2), pp. 303-320.

Hartig, T. (1993) Nature experience in transactional perspective. Landscape and Urban Planning, 25(1-2), pp. 17-36.

Herzog, T. R. (1989) A cognitive analysis of preference for urban nature. Journal of environmental Psychology, 9(1), pp. 27-43.

Lindberg, K., and Johnson, R. L. (1997) Modeling resident attitudes toward tourism. Annals of Tourism Research, 24(2), pp. 402-424.

Matsuoka, R. H., and Kaplan, R. (2008) People needs in the urban landscape: Analysis of landscape and urban planning contributions. Landscape and Urban Planning, 84(1), pp. 7-19.

Mehta, J. N., and Kellert, S. R. (1998) Local attitudes toward community-based conservation policy and programmes in Nepal: A case study in the Makalu-Barun Conservation Area. Environmental Conservation, 25(4), pp. 320-333.

Nastov, A. (2000) Report of nature conservation in The Former Republic of Macedonia. Convention on the conservation of European wildlife and natural habitats. Strasbourg, Council of Europe.

Nastov, A., and Micevski, B. (1994) National report of status of conservation of biological diversity in protected areas of the Republic of Macedonia. Geneva and Skopje, UNEP. 
Obua, J., and Harding, D. M. (1996) Visitor characteristics and attitudes towards Kibale National Park, Uganda. Tourism Management, 17(7), pp. 495-505.

Oguz, D. (2000) User surveys of Ankara's urban parks. Landscape and Urban Planning, 52, pp. 165-171.

Oku, H., and Fukamachi, K. (2006) The differences in scenic perception of forest visitors through their attributes and recreational activity. Landscape and Urban Planning, 75(1-2), pp. 34-42.

Petrosillo, I., Zurlini, G., Corliano, M. E., Zaccarelli, N., and Dadamo, M. (2007) Tourist perception of recreational environment and management in a marine protected area. Landscape and Urban Planning, 79(1), pp. 29-37.

Petrova, S., Bouzarovski-Buzar, S., and Čihař, M. (forthcoming) From inflexible national legislation to flexible local governance: Management practices in the Pelister National Park, Republic of Macedonia. GeoJournal.

Reynolds, G., and Elson, M. J. (1996) The sustainable use of sensitive countryside sites for sport and active recreation. Journal of Environmental Planning and Management, 39(4), pp. 563-576.

Sanesi, G., Lafortezza, R., Bonnes, M., and Carrus, G. (2006) Comparison of two different approaches for assessing the psychological and social dimensions of green spaces. Urban Forestry \& Urban Greening, 5(3), pp. 121-129.

Sherman, S. A., Varni, J. W., Ulrich, R. S., and Malcarne, V. L. (2005) Post-occupancy evaluation of healing gardens in a pediatric cancer center. Landscape and Urban Planning, 73(2-3), pp. 167-183.

Sterl, P., Brandenburg, C., and Arnberger, A. (2008) Visitors' awareness and assessment of recreational disturbance of wildlife in the Donau-Auen National Park. Journal for Nature Conservation, 16(3), pp. 135-145.

Suckall, N., Fraser, E. D. G., Cooper, T., and Quinn, C. (2009) Visitor perceptions of rural landscapes: A case study in the Peak District National Park, England. Journal of Environmental Management, 90(2), pp. 1195-1203.

Taylor, J. (1995) A dream of England: Landscape, photography and the tourist's imagination. Manchester, Manchester University Press.

Ulrich, R. S., Simons, R. F., Losito, B. D., Fiorito, E., Miles, M. A., and Zelson, M. (1991) Stress recovery during exposure to natural and urban environments. Journal of environmental Psychology, 11(3), pp. 201-230.

Urry, J. (1990) The tourist gaze: Leisure and travel in contemporary societies. London, Sage.

Williams, R. (1972) Ideas of nature. In: Benthall, J. (ed.) Ecology: The shaping enquiry, pp. 146-164. London, Longman. 